\title{
Immune responses and gene expression in white shrimp, Litopenaeus vannamei, induced by Lactobacillus plantarum
}

\author{
Chiu-Hsia Chiu ${ }^{\text {a }}$, Yuan-Kuang Guu ${ }^{\text {a }}$, Chun-Hung Liu ${ }^{\text {b }}$, \\ Tzu-Ming Pan ${ }^{\mathrm{c}, * *}$, Winton Cheng ${ }^{\mathrm{b}, *}$ \\ a Department of Food Science, National Pingtung University of Science and Technology, Pingtung 91201, Taiwan \\ ${ }^{\mathrm{b}}$ Department of Aquaculture, National Pingtung University of Science and Technology, 1 Sheuh Fu Road, \\ Nei Pu Hsiang, Pingtung 91201, Taiwan \\ ${ }^{\mathrm{c}}$ Institute of Microbiology and Biochemistry, National Taiwan University, Taipei 10617, Taiwan
}

Received 15 September 2006; revised 22 November 2006; accepted 23 November 2006

Available online 5 December 2006

\begin{abstract}
The total haemocyte counts, phenoloxidase (PO) activity, respiratory bursts, superoxide dismutase (SOD) activity, and phagocytic activity and clearance efficiency to Vibrio alginolyticus, as well as prophenoloxidase (proPO), lipopolysaccharide- and $\beta-1,3-$ glucan-binding protein (LGBP), serine protein (SP), and peroxinectin (PE) mRNA transcription of L. vannamei, and its susceptibility to $V$. alginolyticus when the shrimp were fed diets containing Lactobacillus plantarum at 0 (control), $10^{7}$, and $10^{10} \mathrm{cfu}(\mathrm{kg}$ diet $)^{-1}$ for 48 and $168 \mathrm{~h}$ were evaluated. The results indicated that PO activity, SOD activity, clearance efficiency to $V$. alginolyticus, proPO and PE mRNA transcription, and the survival rate after challenge with $V$. alginolyticus all significantly increased, but the total haemocyte counts significantly decreased in shrimp fed a diet containing Lac. plantarum at $10^{10} \mathrm{cfu}\left(\mathrm{kg}\right.$ diet) ${ }^{-1}$ for $168 \mathrm{~h}$ However, no significant differences in phagocytosis, LGBP, or SP mRNA expression of shrimp were observed among the different treatments. It was concluded that administration of Lac. plantarum in the diet at $10^{10} \mathrm{cfu}(\mathrm{kg} \mathrm{diet})^{-1}$ induced immune modulation and enhanced the immune ability of $L$. vannamei, and increased its resistance to $V$. alginolyticus infection.
\end{abstract}

(c) 2006 Elsevier Ltd. All rights reserved.

Keywords: Litopenaeus vannamei; Lactobacillus plantarum; Probiotics; Phenoloxidase activity; Respiratory bursts; Superoxide dismutase; Haemocyte count; Phagocytic activity; Clearance efficiency; Challenge; Immune gene transcription

\section{Introduction}

White shrimp, Litopenaeus vannamei, which is distributed along the Pacific coast of Central and South America, has been introduced to the Eastern hemisphere, and has become the primary species currently being cultured in Southeast Asian countries. During the past two decades, shrimp culture around the world has suffered problems linked to deteriorating pond environments due to development of intensification, subsequently resulting in stress-induced

\footnotetext{
* Corresponding author. Tel.: +88 68770 3202x6224; fax: +88 687740225 .

** Corresponding author. Tel.: +88 623366 4519; fax: +88 6223627704 .

E-mail addresses: tmpan@ntu.edu.tw (T.-M. Pan), winton@mail.npust.edu.tw (W. Cheng).
} 
disease incidence. Many shrimp farms have been particularly affected by epidemics of viruses and vibriosis. Therefore, the health of shrimp and enhancement of their immunity are of primary concern.

In decapod crustaceans, circulating haemocytes are generally classified into three types, hyaline, semi-granular, and large granular cells [1]. Haemocytes are involved not only in coagulation but also in the production of melanin via the prophenoloxidase (proPO) system, which plays an important defence role [2,3]. Both semi-granular and granular cells carry out functions of the proPO system, which has a role in recognition and defence [2]. Conversion of proPO to phenoloxidase ( $\mathrm{PO}$ ) occurs through prophenoloxidase-activating enzyme (ppA), a serine protease [4]. PO is the terminal enzyme in the proPO system, and ppA is activated by several microbial polysaccharides, including $\beta$-1,3-glucan and lipopolysaccharide (LPS) from fungal cell walls through the non-self recognition system [5]. Specific recognition proteins, including $\beta-1,3$-glucan-binding protein, LPS-binding protein, peptidoglycan-binding protein, and LPS- and $\beta$-1,3-glucan-binding protein (LGBP), which recognise and respond to intruders, have been reported in several crustacean species including penaeid shrimp [6-8].

In addition, peroxinectin (PE), an associated protein of the proPO system, is synthesised and stored in secretory granules of semi-granular cells and granular cells in an inactive form, is released in response to stimulus, and is activated outside the cells to mediate haemocyte attachment and spread $[9,10]$. PE has multiple functions of cell adhesion [9], opsonification [11], degranulation [12], peroxidase activity [13], and encapsulation enhancement [14]. The biological activity of PE is generated concomitantly with activation of the proPO system [13]. PE of L. vannamei has been cloned and characteristic by Liu et al. [15].

Several reactive oxygen species are produced during phagocytosis. Beginning this process, the membrane-bound enzyme complex, NADPH oxidase, assembles after binding the cell to a foreign particle, and reduces molecular oxygen to the superoxide anion $\left(\mathrm{O}_{2}^{-}\right)$, subsequently leading to the production of hydrogen peroxide $\left(\mathrm{H}_{2} \mathrm{O}_{2}\right)$, singlet oxygen $\left({ }^{1} \mathrm{O}_{2}\right)$, hydroxyl radicals $\left(\mathrm{OH}^{\circ}\right)$, and numerous other reactive compounds [16]. The superoxide anion is the first product released from respiratory bursts, and plays an important role in microbicidal activity [17]. Although reactive oxygen intermediates (ROIs) play an especially important role in host defence, host cells can be damaged by the overexpression of ROIs. Most cells have also acquired the relevant protective mechanisms to maintain the lowest possible levels of ROIs inside the cell, including superoxide dismutase (SOD), catalase, and glutathione peroxidase.

Probiotics are defined as live microbial or cultured product feed supplements, which beneficially affect the host by producing inhibitory compounds, competing for chemicals and adhesion sites, modulating and stimulating the immune function, and improving the microbial balance [18-20]. They have been used in aquaculture as a means of disease control, supplementing or even in some cases replacing the use of antimicrobial compounds. A wide range of microalgae (Tetraselmis), yeasts (Debaryomyces, Phaffia, and Saccharomyces), and Gram-positive (Bacillus, Carnobacterium, Enterococcus, Lactobacillus, Lactococcus, Micrococcus, Streptococcus, and Weissella) and Gram-negative bacteria (Aeromonas, Alteromonas, Photorbodobacterium, Pseudomonas, and Vibrio) has been applied as probiotics in fish and shellfish. Applying probiotics to aquaculture ponds and feed to improve aquatic animal growth, survival, health, and disease prevention has been reviewed [20-22].

Administration of probiotics, such as Thalassobacter ultilis PM-4 and Bacillus sp., to elevate the survival rate in commercial shrimp hatcheries and farms has been evaluated [23,24] and reviewed [20]. Probiotics being used to stimulate the immune response of fish has also been considered [25]. However, the effect of probiotics on the immune response and gene expression of shrimp has not been clarified so far. Lactobacillus plantarum is an important species in the fermentation of various plant products [26], is known to produce antimicrobial substances, like plantaricin, that are active against certain pathogens, and is used as a probiotic [27].

The purpose of this study was to examine the immune parameters including total haemocyte counts, PO activity, respiratory bursts, SOD activity, phagocytic activity and clearance efficiency to Vibrio alginolyticus; the immune gene expression including proPO, LGBP, a serine protein, and PE mRNA transcription of L. vannamei; and its susceptibility to $V$. alginolyticus when the shrimp were fed diets containing Lac. plantarum.

\section{Materials and methods}

\subsection{Preparation of the Lac. plantarum mixture}

Lactobacillus plantarum 7-40 (NTU102) isolated from home-made Korean-style cabbage pickles were used in this study. Bacteria were cultured in a sterilised 2-L flask with de Man, Rogosa, and Sharpe (MRS) broth (Merck, 
Darmstadt, Germany) for $24 \mathrm{~h}$ at $37^{\circ} \mathrm{C}$, and then centrifuged at $15,400 \times g$ for $5 \mathrm{~min}$ at $4{ }^{\circ} \mathrm{C}$. The pellet was collected and mixed with skim milk at a ratio of $1: 4$, and then freeze-dried. The bacterial mixture was stored at $4{ }^{\circ} \mathrm{C}$ until used. The viability of the bacterial mixture was determined by plate counting on MRS agar.

\subsection{Preparation of feed}

Three diets containing different levels of bacterial mixture (Lac. plantarum) were prepared as described in Table 1. The composition of the diets was prepared based on a diet used in a previous study [28]. The basal diet contained $0.1 \%$ skim milk. Proximate analysis of the basal diet was $40.7 \%$ crude protein, $7.4 \%$ crude lipid, $13.9 \%$ ash, and $9.0 \%$ moisture. A bacterial mixture (containing $1.01 \times 10^{10} \mathrm{cfu} \mathrm{g}^{-1}$ Lac. plantarum) was added to the test diets at levels of 0.001 and $1.0 \mathrm{~g}(\mathrm{~kg} \mathrm{diet})^{-1}$, resulting in $10^{7}$ and $10^{10} \mathrm{cfu}(\mathrm{kg} \mathrm{diet})^{-1}$, respectively, with corresponding decreases in the amount of skim milk. The ingredients were ground in a Hammer mill so as to pass through a 60-mesh screen. Experimental diets were prepared by mixing the dry ingredients with fish oil and then adding water until a stiff dough resulted. Each diet was then passed through a mincer with a die, and the resulting spaghetti-like strings were dried in a drying cabinet using an air blower at $38{ }^{\circ} \mathrm{C}$ until the moisture levels were at around $10 \%$. After drying, the finished pellets were stored at $-4{ }^{\circ} \mathrm{C}$ until being used.

\subsection{Experimental design}

White shrimp, L. vannamei, obtained from recirculating seawater $(20-23 \%$ ) ponds at the Department of Aquaculture, National Pingtung University of Science and Technology, were acclimated to room temperature $\left(26 \pm 0.5^{\circ} \mathrm{C}\right)$ and a salinity of $20 \%$ in an indoor cement pond $(6 \times 2 \times 1.5 \mathrm{~m})$ with recirculating water for 2 weeks before experimentation. During the acclimation period, shrimp were fed twice daily with the control diet, and $50 \%$ of the water was exchanged weekly to maintain water quality. Only shrimp in the intermolt stage (stage C) were used for the subsequent tests. The molt stage was determined by examination of the uropoda in which partial retraction of the epidermis could be distinguished [29]. Four studies were conducted. For the susceptibility experiment, the test and control groups were comprised of ten shrimp each in triplicate, and were conducted on shrimp following 48 and $168 \mathrm{~h}$ of feeding of Lac. plantarum-containing and control diets. For the study of immune parameters and immune gene assays, tests and controls were carried out on eight replicate test groups consisting of one shrimp each in 20-L PVC tanks containing $10 \mathrm{~L}$ of aerated water. In all tests, shrimp were fed the test diet twice daily. No significant difference in weight was observed among the treatments. During the experiments, the water temperature was maintained at $26 \pm 0.5^{\circ} \mathrm{C}$, the $\mathrm{pH}$ at $7.8-$ 8.2 , and the salinity at $20 \%$.

Table 1

Composition of the basal diet $\left(\mathrm{g} \mathrm{kg}^{-1}\right)$ for Litopenaeus vannamei

\begin{tabular}{lccc}
\hline Ingredients & \multicolumn{2}{c}{ Lactobacillus plantarum in diet $\left(\mathrm{cfu} \mathrm{kg}^{-1}\right)$} & $10^{7}$ \\
\cline { 2 - 4 } & Control & 430 & $10^{10}$ \\
\hline Fish meal & 430 & 50 & 430 \\
Soybean meal & 50 & 25 & 50 \\
Yeast meal & 25 & 70 & 25 \\
Shrimp shell meal & 70 & 353 & 70 \\
Wheat flour & 353 & 1 & 353 \\
Cellulose & 1 & 0.999 & 1 \\
Skim milk & 1 & 0.001 & 1 \\
Probiotic & 0 & 25 & 25 \\
Gluten & 25 & 20 & 20 \\
Fish oil & 20 & 21 & 21 \\
Mineral mixture & 21 & 4 & 4 \\
Vitamin mixture & 4 & & 2 \\
\hline
\end{tabular}

${ }^{a}$ Mineral mix (Shinta Feed Company, Pingtung, Taiwan).

b Vitamin mix (Shinta Feed Company, Pingtung, Taiwan). 


\subsection{Susceptibility of shrimp to V. alginolyticus}

A known pathogenic strain, V. alginolyticus (CH003), isolated from diseased L. vannamei, which displayed symptoms of anorexia, inactivity, poor growth, and necrotic musculature, was used for the study. The pathogen was cultured on tryptic soy agar (TSA supplemented with $1.5 \% \mathrm{NaCl}$, Difco) for $24 \mathrm{~h}$ at $28{ }^{\circ} \mathrm{C}$ before being transferred to $10 \mathrm{ml}$ tryptic soy broth (TSB supplemented with $1.5 \% \mathrm{NaCl}$, Difco), where it remained for $24 \mathrm{~h}$ at $28{ }^{\circ} \mathrm{C}$ as the stock culture for the tests. The broth cultures were centrifuged at $7155 \times \mathrm{g}$ for $15 \mathrm{~min}$ at $4{ }^{\circ} \mathrm{C}$. The supernatant fluids were removed, and the bacterial pellets were re-suspended in a saline solution at $3 \times 10^{7}$ and $1 \times 10^{7}$ as stock bacterial suspensions for the susceptibility study, and at $1 \times 10^{10} \mathrm{cfu} \mathrm{ml}^{-1}$ for the phagocytic activity and clearance efficiency studies.

Challenge trials were carried out in shrimp following 48 and $168 \mathrm{~h}$ of being fed Lac.plantarum-containing and control diets by injecting them with $20 \mu \mathrm{l}$ of a bacterial suspension (at $3 \times 10^{7}$ or $1 \times 10^{7} \mathrm{cfu} \mathrm{ml}^{-1}$ ) resulting in $6 \times 10^{6}$ and $2 \times 10^{6} \mathrm{cfu}$ shrimp ${ }^{-1}$ into the ventral sinus of the cephalothorax, respectively. Shrimp fed the control diet and then saline $(20 \mu \mathrm{l})$ served as the unchallenged control. Experimental shrimp (10 shrimp in each aquarium) were kept in 60-1 glass aquaria containing 401 of water at $20 \%$ and $26 \pm 0.5{ }^{\circ} \mathrm{C}$. There were four treatments for each test. Each treatment used 30 shrimp. Twenty percent of the water was renewed daily, and the experiment lasted $168 \mathrm{~h}$. Shrimp were fed twice daily with the test diets after challenge.

\subsection{Immune parameters of the shrimp}

The immune parameters of the shrimp following feeding with different levels of Lac. plantarum-containing diets were determined at the beginning and after 24,72 , and $168 \mathrm{~h}$ of feeding. Haemolymph $(100 \mu \mathrm{l})$ was withdrawn from the ventral sinus of each shrimp into a $1-\mathrm{ml}$ sterile syringe (25-gauge) containing $0.9 \mathrm{ml}$ anticoagulant solution ( $30 \mathrm{mM}$ trisodium citrate, $0.34 \mathrm{M}$ sodium chloride, and $10 \mathrm{mM}$ EDTA, at a $\mathrm{pH}$ of 7.55 and with the osmolality adjusted with glucose to $780 \mathrm{mOsm} \mathrm{kg}^{-1}$ ). They were divided into two parts. A drop of the anticoagulant-haemolymph mixture $(100 \mu \mathrm{l})$ was placed on a haemocytometer to measure the THC using an inverted phase-contrast microscope (Leica DMIL, Leica Microsystems, Wetzlar, Germany). The remainder of the haemolymph mixture was used for subsequent tests.

PO activity of haemocytes was measured spectrophotometrically by recording the formation of dopachrome produced following the procedures of Hernãndez-López et al. [30]. The L-3, 4-dihydroxyphenylalanine and trypsin were served as a substrate and an elicitor, respectively. The details of the measurement were described previously [31]. The optical density of the shrimp's PO activity was expressed as dopachrome formation in $50 \mu$ of haemolymph.

Respiratory bursts of haemocytes were quantified using the reduction of nitroblue tetrazolium (NBT) to formazan as a measure of superoxide anion $\left(\mathrm{O}_{2}^{-}\right)$formation as described previously [17]. The optical density at $630 \mathrm{~nm}$ was measured using a microplate reader (Model VERSAmax, Molecular Devices, Sunnyvale, CA, USA). Respiratory bursts were expressed as NBT-reduction per $10 \mu \mathrm{l}$ of haemolymph.

SOD activity of haemocytes was measured by its ability to inhibit superoxide radical-dependent reactions using the Ransod kit (Randox, Crumlin, UK) based on the methods described in the instructions. Briefly, the reaction mixture $(1.7 \mathrm{ml})$ contained $0.05 \mathrm{mM}$ xanthine and $0.025 \mathrm{mM}$ 2-(4-iodophenyl)-3-(4-nitrophenol)-5-phenyltetrazolium chloride (INT) dissolved in $50 \mathrm{mM}$ CAPS ( $\mathrm{pH} \mathrm{10.2)} \mathrm{and} 0.94 \mathrm{mM}$ EDTA. In the presence of xanthine oxidase $\left(80 \mathrm{U} \mathrm{L}^{-1}, 250 \mu \mathrm{l}\right)$, superoxide and uric acid were produced from xanthine. The superoxide radical then reacted with INT to produce a red formazan dye. The optical density was measured at $505 \mathrm{~nm}$ and $37^{\circ} \mathrm{C}$, and the rate of the reaction was estimated from the absorbance readings 0.5 and $3 \mathrm{~min}$ after adding xanthine oxidase. A reference standard (SOD) was supplied with the Ransod kit. The unit of SOD was calculated according to the ratio of xanthine inhibition of the SOD standard. Specific activity was expressed as SOD units (mg protein) ${ }^{-1}$.

The total protein was quantified as described by Bradford [32] using a Bio-Rad Protein Assay Kit (no. 500-0006, Bio-Rad Laboratories, USA) with bovine serum albumin as a standard.

\subsection{Phagocytic activity and clearance efficiency of shrimp to V. alginolyticus}

For the phagocytic activity and clearance efficiency tests, $20 \mu \mathrm{l}$ of a bacterial suspension $\left(1 \times 10^{10} \mathrm{cfu} \mathrm{ml}^{-1}\right)$ resulting in $2 \times 10^{8} \mathrm{cfu}_{\text {shrimp }}{ }^{-1}$ was injected into the ventral sinus. After injection, the shrimp were kept for $3 \mathrm{~h}$ in 
separate tanks containing $40 \mathrm{~L}$ of seawater $(20 \%)$ at $26 \pm 1{ }^{\circ} \mathrm{C}$. Then, $200 \mu \mathrm{l}$ of haemolymph was collected from the ventral sinus and mixed with $200 \mu \mathrm{l}$ of sterile anticoagulant. This mixture was divided into two equal sub-samples: one to measure phagocytic activity and the other to measure clearance efficiency.

The methods for the measurements of phagocytic activity and clearance efficiency were described previously [31]. Two hundred haemocytes were counted. Phagocytic activity, defined as the phagocytic rate (PR), was expressed as:

$$
\mathrm{PR}=[(\text { phagocytic hemocytes }) /(\text { total hemocytes })] \times 100
$$

The clearance efficiency, defined as percentage inhibition (PI) of V.alginolyticus, was calculated as:

$$
\mathrm{PI}=100-[(\text { cfu in the test group }) /(\mathrm{cfu} \text { in the control group })] \times 100
$$

\subsection{Quantification of shrimp immune genes}

The immune genes of shrimp following feeding on different levels of Lac. plantarum-containing diets were determined by quantitative real-time RT-PCR at the beginning and after 24, 72, and $168 \mathrm{~h}$ of feeding. Haemocytes of shrimp were collected as described above. Total RNA of haemocytes was extracted and purified using the guanidinium thiocyanate method [33]. The RNA was adjusted to the same concentration with DEPC-water and accurately quantified with a spectrophotometer. First-strand cDNA synthesis by reverse transcription (RT) was accomplished using SuperScript II RNase $\mathrm{H}^{-}$reverse transcriptase (Promega Corp., Madison, WI, USA) to transcribe poly $(\mathrm{A})^{+}$RNA with oligo-d(T) ${ }_{18}$ as the primer. Reaction conditions recommended by the manufacturer were followed.

For quantification of the shrimp immune genes, the specific primer pairs of prophenoloxidase (proPO), peroxinectin (PE), lipopolysaccharide- and $\beta$-1,3-glucan-binding protein (LGBP), a serine protein (SP), and $\beta$-actin were designed as follows: proPO forward primer, $5^{\prime}$-GCCTTGGCAACGCTTTCA- $3^{\prime}$ and reverse primer, CGCGCATCA GTTCAGTTTGT-3' [34]; LGBP forward primer, 5'-CATGTCCAACTTCGCTTTCAGA-3' and reverse primer, 5'ATCACCGCGTGGCATCTT-3' [8]; PE forward primer, 5'-TGGACCTCGCGGGAGAT-3' and reverse primer, 5'-GACCGATAGCCACCATGCTT-3' [15]; SP forward primer, 5'-CGTCGTTAGGTTAAGTGCGTTCT-3' and reverse primer, $5^{\prime}$-TTTCAGCGCATTAAGACGTGTT-3' [35]; and $\beta$-actin forward primer, $5^{\prime}$-GAGCAACACGG AGTTCGTTGT-3' and reverse primer, 5'-CATCACCAACTGGGACGACATGGA-3' (GenBank accession no.: AF300705).

The SYBR green I real-time RT-PCR assay was carried out in an ABI PRISM ${ }^{\mathrm{TM}} 7900$ Sequence Detection System (Applied Biosystems, Foster City, CA, USA). The amplifications were performed in a 96-well plate in a 25- $\mu 1$ reaction volume containing $12.5 \mu \mathrm{l}$ of $2 \times$ SYBR Green Master Mix (PE Applied Biosystems), $2.5 \mu \mathrm{l}$ (each) of the forward and reverse primers $(10 \mu \mathrm{M}), 1 \mu \mathrm{l}$ of template $(1 \mu \mathrm{g}$ cDNA), and $9 \mu \mathrm{l}$ of DEPC-water. The thermal profile for the SYBR green real-time RT-PCR was $50{ }^{\circ} \mathrm{C}$ for $2 \mathrm{~min}$ and $95^{\circ} \mathrm{C}$ for $10 \mathrm{~min}$ followed by 40 cycles of $95^{\circ} \mathrm{C}$ for $15 \mathrm{~s}$ and $60{ }^{\circ} \mathrm{C}$ for $1 \mathrm{~min}$. In a 96-well plate, each sample was analysed in duplicate. DEPC-water replaced the template as the negative control.

Data analysis of the RT-PCR was performed with SDS software version 2.0 (Perkin-Elmer Applied Biosystems). Relative quantification of gene expression was performed according to the manufacturer's instructions. Briefly, the threshold PCR cycle $(\mathrm{Ct})$ was defined as the cycle number at which a statistically significant increase in the fluorescence of SYBR green against the internal passive dye, $\operatorname{ROX}\left(\Delta R_{\mathrm{n}}\right)$, was first detected. The copy number of the target gene and $\mathrm{Ct}$ values were inversely related; thus, a sample containing a higher number of copies of the target gene had a lower $\mathrm{Ct}$ value than that of a sample with a lower number of copies of the same target. Differences in the $\mathrm{Ct}$ values of immune genes and the corresponding internal control $\beta$-actin gene, called $\Delta \mathrm{Ct}$, were calculated to normalise any differences in the amount of total RNA added to the cDNA reaction mixture and the efficiency of the reverse-transcription reaction. The value of $\Delta \mathrm{Ct}$ in the treated sample was subtracted from the value of $\Delta \mathrm{Ct}$ of the control sample. The difference was expressed as the $\Delta \Delta \mathrm{Ct}$ value that allowed measurement of the change in the expression of immune genes in the treated sample relative to the control sample. A 3.3-fold change in the Ct value is considered to be equivalent to a 10 -fold change in expression. 


\subsection{Statistical analysis}

A multiple comparison (Tukey's) test was conducted to examine the significant differences among treatments using the SAS computer software (SAS Institute, Cary, NC, USA). Before analysis, percent data were normalised using arcsine transformation before analysis. It was required that $p<0.05$ to achieve statistical significance.

\section{Results}

\subsection{Challenge tests}

White shrimp, L. vannamei, following feeding with Lac. plantarum-containing and control diets after $48 \mathrm{~h}$ and $168 \mathrm{~h}$ were challenged with $V$. alginolyticus. All unchallenged control shrimp survived in the two challenge trials. The cumulative mortality of shrimp following feeding with different Lac. plantarum-containing diets for $48 \mathrm{~h}$, and then challenge with $V$. alginolyticus did not significantly differ in any time interval. With the same treatments after $168 \mathrm{~h}$ and then challenge with $V$. alginolyticus, the cumulative mortality of shrimp fed $10^{10} \mathrm{cfu}(\mathrm{kg} \mathrm{diet})^{-1}$ of the Lac. plantarum-containing diet was significantly lower than that of shrimp fed the control diet after $144 \mathrm{~h}$. After $168 \mathrm{~h}$ of challenge, the cumulative mortalities of shrimp fed the $0,10^{7}$, and $10^{10} \mathrm{cfu}(\mathrm{kg} \mathrm{diet})^{-1}$ Lac. plantarumcontaining diets were $43.3 \%, 33.3 \%$, and $23.3 \%$, respectively (Table 2 ).

\subsection{Immune parameters of shrimp}

The total haemocyte count (THC) of shrimp fed the diet containing Lac. plantarum at $10^{10} \mathrm{cfu}(\mathrm{kg} \text { diet })^{-1}$ after $48 \mathrm{~h}$ was significantly lower than that of shrimp fed the control diet. After $168 \mathrm{~h}$ of feeding, the THCs of shrimp fed the diets containing Lac. plantarum at $10^{7}$ and $10^{10} \mathrm{cfu}(\mathrm{kg} \text { diet })^{-1}$ were significantly lower than that of shrimp fed the control diet. However, no significant differences in the THCs were detected between shrimp fed the diets containing Lac. plantarum at $10^{7}$ and $10^{10} \mathrm{cfu}\left(\mathrm{kg}\right.$ diet) ${ }^{-1}$. The relative THC (compared to the THC of shrimp fed the control diet) of shrimp fed the $10^{7}$ and $10^{10} \mathrm{cfu}(\mathrm{kg} \mathrm{diet})^{-1}$ Lac. plantarum-containing diets decreased to $77.8 \%$ and $72.4 \%$, respectively (Fig. 1).

The phenoloxidase activity of shrimp receiving the diet containing $10^{10} \mathrm{cfu}\left(\mathrm{kg}\right.$ diet) ${ }^{-1}$ Lac. plantarum was significantly lower than that of shrimp fed the control diet at $48 \mathrm{~h}$. In contrast, those of shrimp fed the $10^{7}$ and $10^{10} \mathrm{cfu}(\mathrm{kg}$ diet $)^{-1}$ Lac. plantarum-containing diets were significantly higher than that of shrimp fed the control diet after $168 \mathrm{~h}$. The relative phenoloxidase activity levels (compared to the activity of shrimp fed the control diet) of shrimp fed the $10^{7}$ and $10^{10} \mathrm{cfu}(\mathrm{kg} \mathrm{diet})^{-1}$ Lac. plantarum-containing diets increased to $156.5 \%$ and $137.0 \%$, respectively (Fig. 2).

The respiratory bursts of shrimps fed the $10^{7} \mathrm{cfu}(\mathrm{kg} \mathrm{diet})^{-1}$ Lac. plantarum-containing diet were significantly higher than those of shrimp fed the $10^{10} \mathrm{cfu}(\mathrm{kg} \mathrm{diet})^{-1}$ Lac. plantarum-containing diet and the control diet after 48 and $168 \mathrm{~h}$. However, no significant differences in respiratory bursts of shrimp were observed between shrimp fed the $10^{10} \mathrm{cfu}(\mathrm{kg} \mathrm{diet})^{-1}$ Lac. plantarum-containing diet and the control diet from 48 to $168 \mathrm{~h}$. The relative respiratory bursts (compared to the activity of shrimp fed the control diet) of shrimp following 48 and $168 \mathrm{~h}$ of feeding the $10^{7} \mathrm{cfu}(\mathrm{kg} \mathrm{diet})^{-1}$ Lac. plantarum-containing diets increased to $216.2 \%$ and $174.1 \%$, respectively (Fig. 3).

Table 2

Cumulative mortality (mean \pm S.E.) of Litopenaeus vannamei challenged with Vibrio alginolyticus, when the shrimp were fed different levels of Lactobacillus plantarum $\left(0,10^{7}, 10^{10} \mathrm{cfu} \mathrm{kg}^{-1}\right)$ containing diets after $168 \mathrm{~h}$

\begin{tabular}{|c|c|c|c|c|c|c|c|c|}
\hline \multirow{2}{*}{$\begin{array}{l}\text { Bacteria } \\
\left(\text { cfu shrimp }^{-1}\right)\end{array}$} & \multirow{2}{*}{$\begin{array}{l}\text { Lactobacillus } \\
\text { plantarum in diet } \\
\left(\mathrm{cfu} \mathrm{kg}^{-1}\right)\end{array}$} & \multirow{2}{*}{$\begin{array}{l}\text { No. of } \\
\text { Shrimp }\end{array}$} & \multicolumn{6}{|c|}{ Cumulative mortality $(\%)$ after time elapsed } \\
\hline & & & 6 & 12 & 24 & 48 & 144 & 168 \\
\hline Saline & 0 & 30 & 0 & 0 & 0 & 0 & 0 & 0 \\
\hline $2 \times 10^{5}$ & 0 & 30 & $3.3 \pm 3.3^{\mathrm{a}}$ & $20.0 \pm 5.8^{\mathrm{a}}$ & $30.0 \pm 0^{\mathrm{a}}$ & $33.3 \pm 3.3^{\mathrm{a}}$ & $43.3 \pm 3.3^{\mathrm{a}}$ & $43.3 \pm 3.3^{\mathrm{a}}$ \\
\hline $2 \times 10^{5}$ & $10^{7}$ & 30 & $13.3 \pm 3.3^{\mathrm{a}}$ & $30.0 \pm 0^{\mathrm{a}}$ & $30.0 \pm 0^{\mathrm{a}}$ & $30.0 \pm 0^{\mathrm{a}}$ & $33.3 \pm 3.3^{\mathrm{ab}}$ & $33.3 \pm 3.3^{\mathrm{ab}}$ \\
\hline $2 \times 10^{5}$ & $10^{10}$ & 30 & $3.3 \pm 3.3^{\mathrm{a}}$ & $20.0 \pm 5.8^{\mathrm{a}}$ & $26.7 \pm 6.7^{\mathrm{a}}$ & $26.7 \pm 6.7^{\mathrm{a}}$ & $23.3 \pm 3.3^{\mathrm{b}}$ & $23.3 \pm 3.3^{\mathrm{b}}$ \\
\hline
\end{tabular}

Data in the same column with different letters significantly differ $(P<0.05)$ among different treatments. Values are mean \pm S.E. 


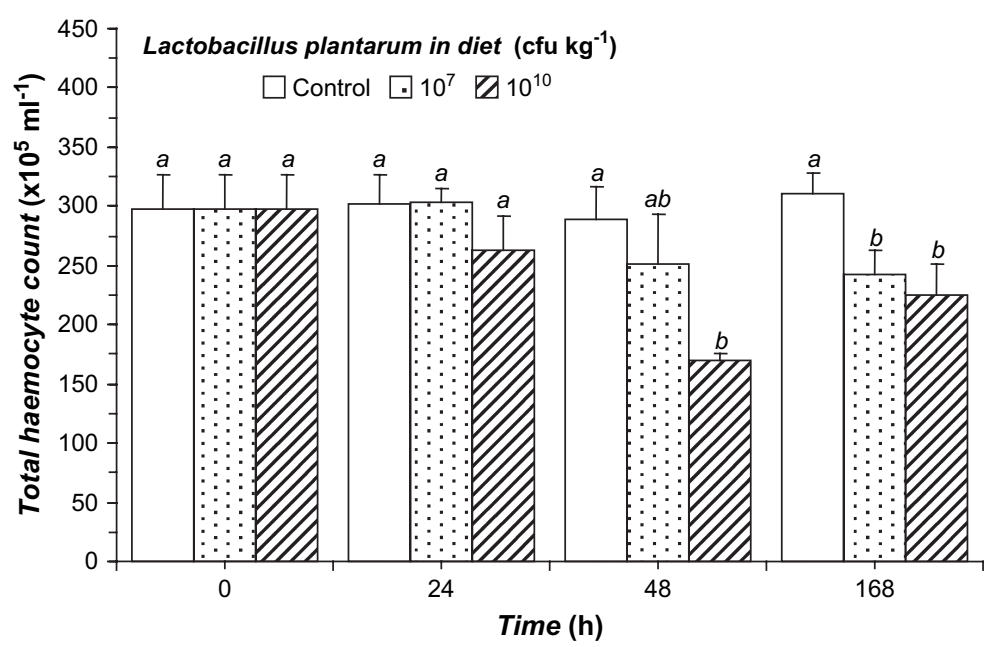

Fig. 1. Total haemocyte counts of Litopenaeus vannamei fed the control diet and Lactobacillus plantarum-containing diets at $10^{7}$ and $10^{10} \mathrm{cfu}(\mathrm{kg}$ diet $)^{-1}$, respectively. Each bar represents the mean value from eight determinations with the standard error. Data (mean \pm S.E.) with different letters significantly differ $(p<0.05)$ among treatments.

The superoxide dismutase activity in haemocytes of shrimp fed the $10^{10} \mathrm{cfu}(\mathrm{kg} \mathrm{diet})^{-1}$ Lac. plantarum-containing diet was significantly higher than those of shrimp fed the $10^{7} \mathrm{cfu}(\mathrm{kg} \mathrm{diet})^{-1}$ Lac. plantarum-containing diet and the control diet from 24 to $168 \mathrm{~h}$. The relative superoxide dismutase activity (compared to the activity of shrimp fed the control diet) of shrimp following 24,48 , and $168 \mathrm{~h}$ of feeding the $10^{10} \mathrm{cfu}(\mathrm{kg} \mathrm{diet})^{-1}$ Lac.plantarum-containing diets increased to $420.9 \%, 244.3 \%$, and $496.6 \%$, respectively (Fig. 4).

No significant differences in phagocytic activity of shrimp were observed among the three treatments from 24 to $168 \mathrm{~h}$.

The clearance efficiency, an overall antibacterial indicator, of shrimp was significantly enhanced when shrimp were fed the $10^{7}$ and $10^{10} \mathrm{cfu}(\mathrm{kg} \mathrm{diet})^{-1}$ Lac. plantarum-containing diets from 48 to $168 \mathrm{~h}$. The clearance efficiencies of shrimp following $48 \mathrm{~h}$ of feeding the $10^{7}$ and $10^{10} \mathrm{cfu}(\mathrm{kg} \mathrm{diet})^{-1}$ Lac. plantarum-containing diets increased by $79.8 \%$ and $74.4 \%$, respectively, and following $168 \mathrm{~h}$ of feeding the $10^{7}$ and $10^{10} \mathrm{cfu}(\mathrm{kg} \mathrm{diet})^{-1}$ Lac. plantarum-containing diets, they increased by $82.4 \%$ and $66.6 \%$, respectively (Fig. 5).

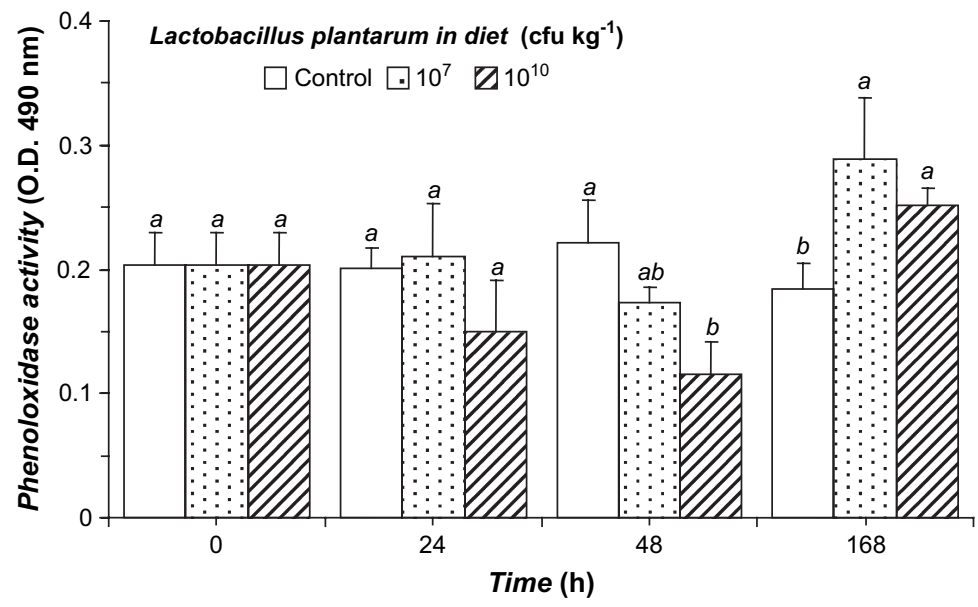

Fig. 2. Phenoloxidase activity of Litopenaeus vannamei fed the control diet and Lactobacillus plantarum-containing diets at $10^{7}$ and $10^{10} \mathrm{cfu}(\mathrm{kg}$ diet $)^{-1}$, respectively. See Fig. 1 for statistical information. 


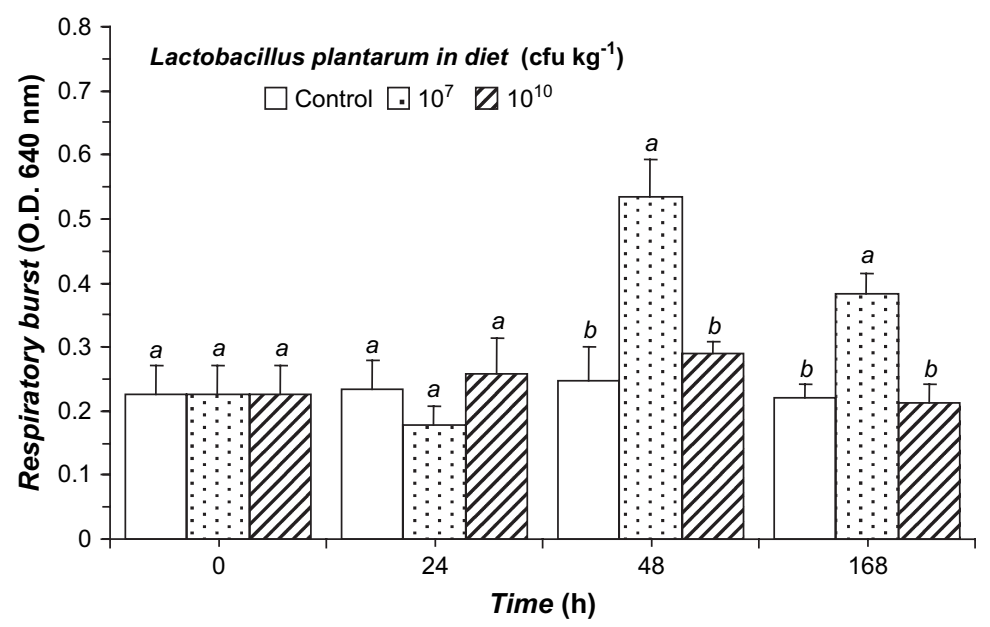

Fig. 3. Respiratory bursts of Litopenaeus vannamei fed the control diet and Lactobacillus plantarum containing diets at $10^{7}$ and $10^{10} \mathrm{cfu}\left(\mathrm{kg}\right.$ diet) ${ }^{-1}$, respectively. See Fig. 1 for statistical information.

\subsection{Expression of immune genes}

mRNA expressions of immune genes of shrimps fed the $0,10^{7}$, and $10^{10} \mathrm{cfu}(\mathrm{kg} \mathrm{diet})^{-1}$ Lac. plantarum-containing diets were measured using real-time RT-PCR at the beginning and after 48 and $168 \mathrm{~h}$. No significant differences in LGBP mRNA transcriptions of shrimp were observed among the three treatments from 24 to $168 \mathrm{~h}$.

The proPO mRNA expression levels of shrimp which had been fed the $10^{7}$ and $10^{10} \mathrm{cfu}(\mathrm{kg} \mathrm{diet})^{-1}$ Lac. plantarumcontaining diets after $168 \mathrm{~h}$ were significantly higher than that of shrimp fed the control diet. The proPO gene expression levels of shrimp fed the $10^{7}$ and $10^{10} \mathrm{cfu}(\mathrm{kg} \mathrm{diet})^{-1}$ Lac. plantarum-containing diets were -2.0 and -1.5 , respectively, relative to shrimp fed the control diet after $168 \mathrm{~h}$. Shrimp fed the $10^{7}$ and $10^{10} \mathrm{cfu}(\mathrm{kg} \mathrm{diet})^{-1}$ Lac. plan- $^{1}$ tarum-containing diets had approximately 6.1- and 4.4-fold higher expression levels of proPO mRNA, respectively, than did shrimp fed the control diet after $168 \mathrm{~h}$ (Fig. 6A,B).

No significant differences in serine protease mRNA transcription levels of shrimp were observed among the three treatments from 24 to $168 \mathrm{~h}$.

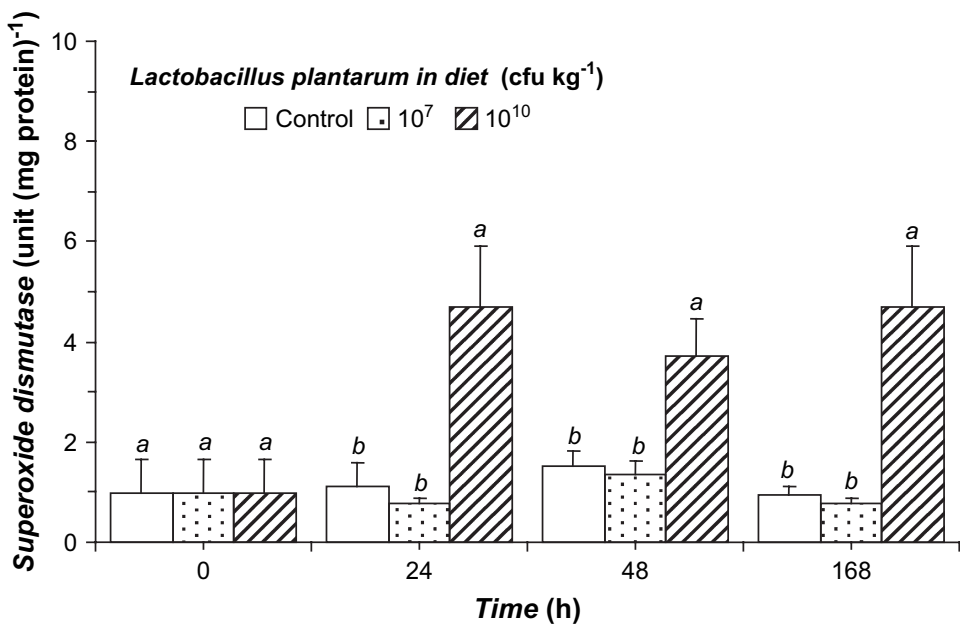

Fig. 4. Superoxide dismutase of Litopenaeus vannamei fed the control diet and Lactobacillus plantarum-containing diets at $10^{7}$ and $10^{10} \mathrm{cfu}\left(\mathrm{kg}\right.$ diet) ${ }^{-1}$, respectively. See Fig. 1 for statistical information. 


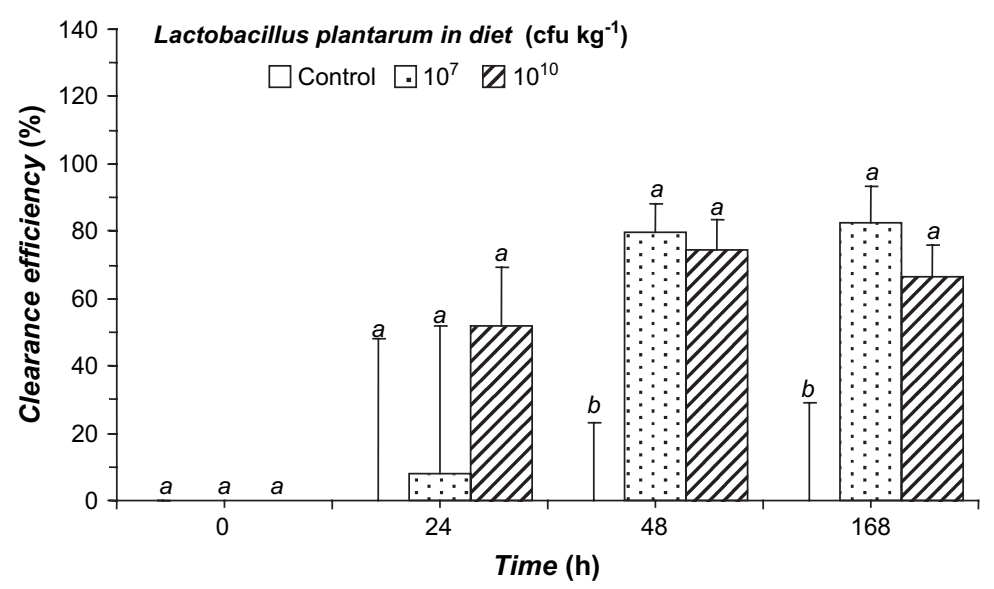

Fig. 5. Clearance efficiency of Litopenaeus vannamei fed the control diet and Lactobacillus plantarum-containing diets at $10^{7}$ and $10^{10}$ cfu $(\mathrm{kg} \mathrm{diet})^{-1}$, respectively. See Fig. 1 for statistical information.

The PE mRNA transcription levels of shrimp fed the $10^{7}$ and $10^{10} \mathrm{cfu}(\mathrm{kg} \mathrm{diet})^{-1}$ Lac. plantarum-containing diets were significantly higher than that of shrimp fed the control diet after $168 \mathrm{~h}$. The PE gene expression levels of shrimp fed the $10^{7}$ and $10^{10} \mathrm{cfu}(\mathrm{kg} \mathrm{diet})^{-1}$ Lac. plantarum-containing diets were -1.4 and -1.2 , respectively, relative to shrimp fed the control diet after $168 \mathrm{~h}$. Shrimp fed the $10^{7}$ and $10^{10} \mathrm{cfu}(\mathrm{kg} \mathrm{diet})^{-1}$ Lac. plantarum-containing diets had approximately 4.3- and 3.7-fold higher expression levels of PE mRNA, respectively, than did shrimp fed the control diet after $168 \mathrm{~h}$ (Fig. 7A,B).

\section{Discussion}

In the present study, white shrimp receiving Lac. plantarum-containing diets exhibited enhanced immune modulation resulting in increased resistance against a pathogen, similar to that reported with the administration of probiotics in several vertebrate $[25,36-42]$.

Chang and Liu [43] used Enterococcus faecium SF 68 from commercial products to reduce edwardsiellosis in European eel, Anguilla anguilla, resulting in reduced mortality of eels and suppressed growth of E. tarda in vitro. The human probiotic, Lactobacillus rhamnosus ATCC (American Type Culture Collection, Rockville, MD, USA) 53101, was administered at a dose of $10^{9}$ and $10^{12}$ cells $\mathrm{g}^{-1}$ of feed to rainbow trout, Oncorhynchus mykiss, for 51 days, and reduced mortalities from $52.6 \%$ to $18.9 \%$ (at $10^{9}$ cells g ${ }^{-1}$ of feed) and to $46.3 \%$ (at $10^{12}$ cells g g $^{-1}$ of feed) following challenge with Aeromonas salmonicida [44]. Maeda and Liao [23] reported that the soil bacterial strain, PM-4, promoted the growth of Penaeus monodon nauplii. This strain also showed an in vitro inhibitory effect against a $V$. anguillarum strain. When added to tanks inoculated with diatoms and rotifers, the strain resulted in 57\% survival of the larvae after 13 days, while without the bacterium all the larvae had died after 5 days [45]. After being fed for 100 days with Bacillus strain S11-supplemented feed, P. monodon postlarvae were challenged with a pathogenic $V$. harveyi strain, D331, by immersion of the shrimp. After 10 days, all groups treated with the S11 Bacillus strain showed $100 \%$ survival, whereas the control group had only $26 \%$ survival [24]. In the present study, white shrimp, L. vannamei, following feeding with Lac. plantarum-containing diets for $168 \mathrm{~h}$, were challenged with $V$. alginolyticus and showed reduced mortalities of from $43.3 \%$ to $33.3 \%$ (at $10^{7} \mathrm{cfu} \mathrm{kg}^{-1}$ of feed) and to $23.3 \%$ (at $10^{10} \mathrm{cfu} \mathrm{kg}^{-1}$ of feed) indicating that L. plantarum 7-40 (NTU102) has the potential as a probiotic to improve white shrimp, $L$. vannamei, resistance against $V$. alginolyticus infection.

It is well known that the life cycle, food intake, disease outbreak, pollutants, and environmental stress affect the circulating haemocyte count of crustaceans, both in quantity and quality [46-48]. An increase in the THC provides enhanced immune capability during periods of stress [49] leading to disease resistance in crustaceans [50]. There is a direct relationship between the bacterial concentration in the water and in haemolymph [51]. In the present study, the THCs of shrimp fed diets containing Lac. plantarum at $10^{7}$ and $10^{10} \mathrm{cfu}(\mathrm{kg} \mathrm{diet})^{-1}$ were significantly lower at $168 \mathrm{~h}$ and at 48-168 h, respectively, than that of shrimp fed the control diet. These facts suggest that after a certain period, 

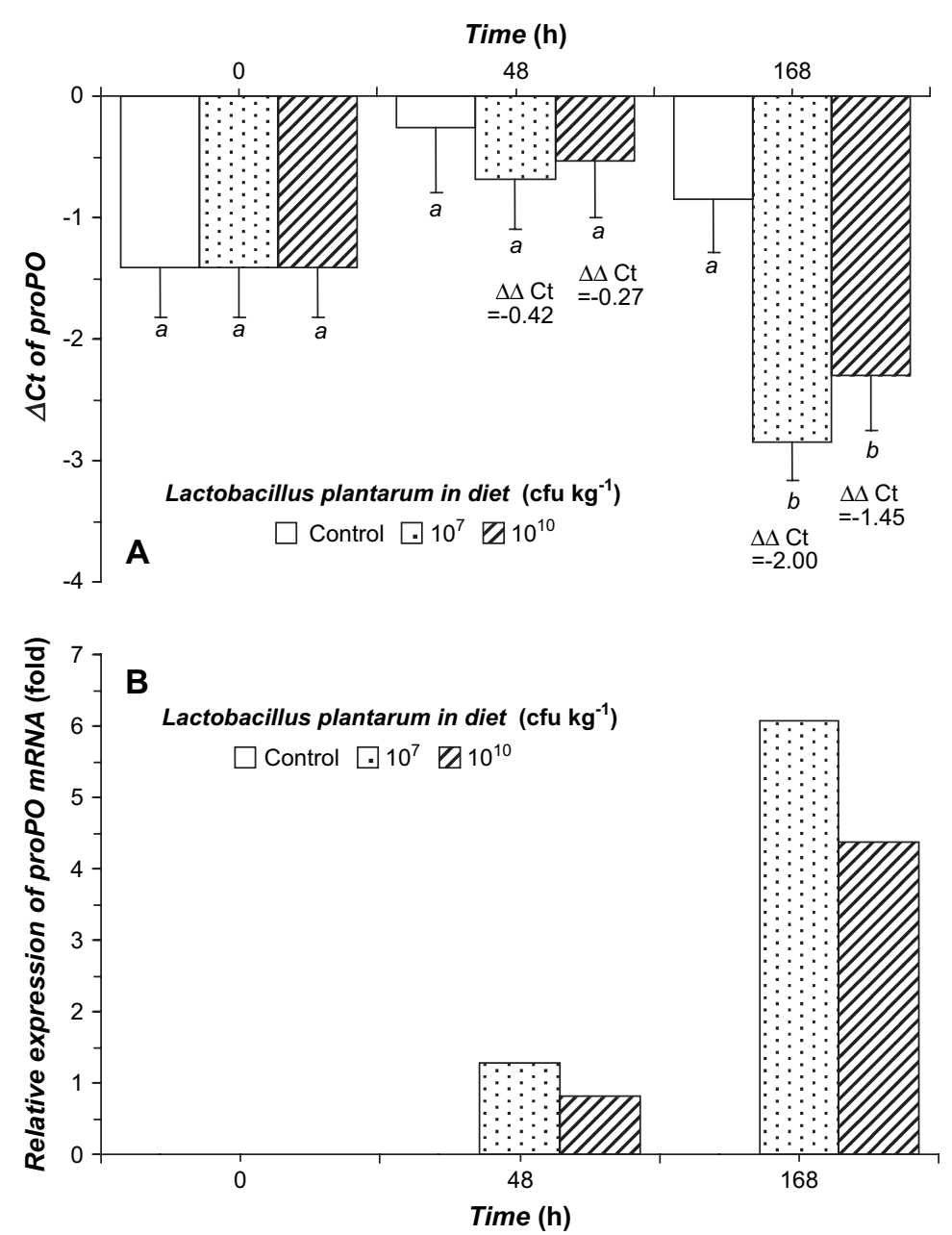

Fig. 6. Measurement of prophenoloxidase (proPO) mRNA expression in Litopenaeus vannamei fed the control diet and fed the Lactobacillus plantarum-containing diets at $10^{7}$ and $10^{10} \mathrm{cfu}\left(\mathrm{kg}\right.$ diet) ${ }^{-1}$, respectively, by SYBR green RT-PCR. Each bar represents the $\Delta \mathrm{Ct}$ of proPO (the $\mathrm{Ct}$ value of the proPO gene minus the $\mathrm{Ct}$ value of the $\beta$-actin gene) as measured by SYBR green RT-PCR. Numbers above the bars indicate the $\Delta \Delta \mathrm{Ct}$ value (the $\Delta \mathrm{Ct}$ value of proPO in each treatment shrimp minus the $\Delta \mathrm{Ct}$ value of proPO in control shrimp) (A). A Ct value change $(\Delta \Delta \mathrm{Ct})$ of 3.3 is equivalent to a 10-fold difference between the control and treatments (B). Bars in the same treatment time interval with different letters significantly differ $(p<0.05)$ among shrimp with different treatments.

shrimp fed the Lac. plantarum-containing diets may have increased bacterial levels in the digestive tract or the test water may have induced more haemocytes to attach to the epidermis to offer better protection. Unfortunately, bacterial levels in the digestive tract or test water were not determined in this study.

In the present study, the THCs of shrimp fed the diets containing Lac. plantarum at $10^{7}$ and $10^{10} \mathrm{cfu}(\mathrm{kg} \mathrm{diet})^{-1}$ were significantly lower at $168 \mathrm{~h}$ and $48-168 \mathrm{~h}$, respectively, than those of shrimp fed the control diet. The phenoloxidase (PO) activity of shrimp fed diets containing Lac. plantarum at $10^{7}$ and $10^{10} \mathrm{cfu}\left(\mathrm{kg}\right.$ diet) ${ }^{-1}$ were lower at $48 \mathrm{~h}$, but significantly higher at $168 \mathrm{~h}$ than those of shrimp fed the control diet. In addition, the mRNA transcription of proPO in shrimp fed the $10^{7}$ and $10^{10} \mathrm{cfu}(\mathrm{kg} \mathrm{diet})^{-1}$ Lac. plantarum-containing diets after $168 \mathrm{~h}$ were significantly higher than that of shrimp fed the control diet. However, the cumulative mortality of shrimp following feeding on different levels of Lac. plantarum-containing diets for $48 \mathrm{~h}$ and then challenge with $V$. alginolyticus did not significantly differ at any time interval. These facts suggest that the PO activity of shrimp decreases as a consequence of the decrease in the circulating haemocyte count after $48 \mathrm{~h}$ of feeding. After $168 \mathrm{~h}$ of feeding, upregulation of proPO mRNA by the shrimp resulted in increased PO activity which enhanced the resistance against the pathogen, V. alginolyticus. 

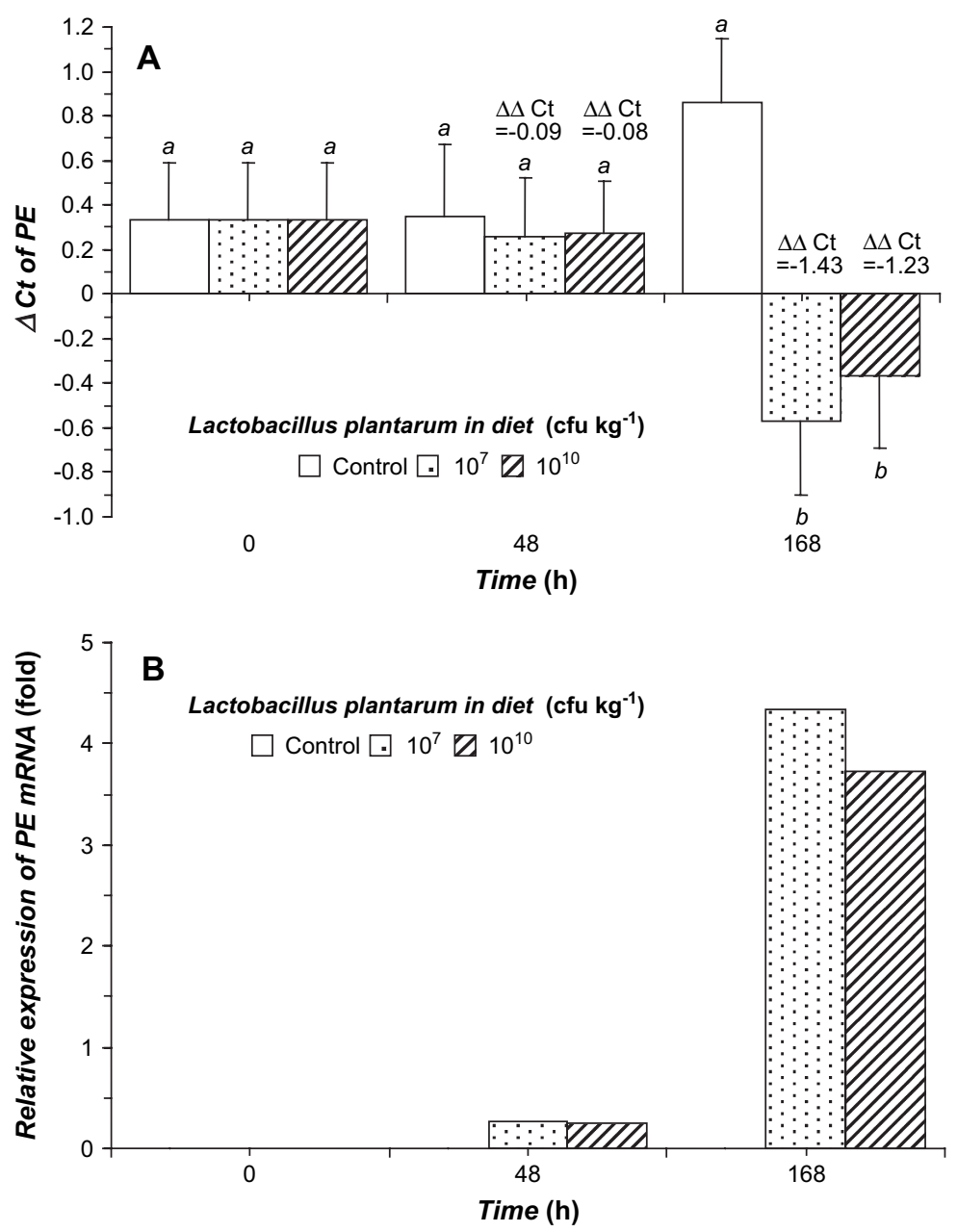

Fig. 7. Measurement of peroxinectin (PE) mRNA expression in Litopenaeus vannamei fed the control diet and fed the Lactobacillus plantarumcontaining diets at $10^{7}$ and $10^{10} \mathrm{cfu}(\mathrm{kg} \text { diet })^{-1}$, respectively, by SYBR green RT-PCR. Each bar represents the $\Delta \mathrm{Ct}$ of PE (the Ct value of the PE gene minus the $\mathrm{Ct}$ value of the $\beta$-actin gene) as measured by SYBR green RT-PCR. Numbers above the bars indicate the $\Delta \Delta \mathrm{Ct}$ value (the $\Delta \mathrm{Ct}$ value of $\mathrm{PE}$ in each treatment shrimp minus the $\Delta \mathrm{Ct}$ value of $\mathrm{PE}$ in control shrimp) (A). A Ct value change ( $\Delta \Delta \mathrm{Ct}$ ) of 3.3 is equivalent to a 10 -fold difference between the control and treatment groups (B). See Fig. 6 for statistical information.

Respiratory bursts in haemocytes have been widely used to evaluate the defence ability against pathogens in shrimp [28,52]. They are produced by phagocytes in order to attack invasive pathogens during phagocytosis. Rainbow trout fed Lac. rhamnosus demonstrated a significant increase in respiratory burst activity of blood cells [40]. Also, the phagocytic activity of head kidney leucocytes increased in rainbow trout fed the same species [41]. A similar response was reported in gilthead seabream, Sparus aurata, fed Lac. delbrueckii [42], and rainbow trout, Oncorhynchus mykiss, fed Carnobacterium maltaromaticum B26 and C. divergens B33 at a dose $>10^{7}$ cells (g diet) ${ }^{-1}[25]$.

In the present study, the phagocytic activities of shrimp insignificantly differed among different treatments. Respiratory bursts of haemocytes increased in shrimp following feeding of the $10^{7} \mathrm{cfu}(\mathrm{kg} \mathrm{diet})^{-1}$ Lac. plantarum-containing diet from 48 to $168 \mathrm{~h}$, and showed an insignificant change in shrimp following feeding with the $10^{10} \mathrm{cfu}(\mathrm{kg}$ diet) ${ }^{-1}$ Lac. plantarum-containing diet for $168 \mathrm{~h}$. The superoxide dismutase (SOD) activity and peroxinectin (a multifunctional protein containing biological activity of peroxidase) mRNA transcription level of shrimp following feeding with the $10^{10} \mathrm{cfu}(\mathrm{kg} \mathrm{diet})^{-1}$ Lac. plantarum-containing diet significantly increased from 24 to $168 \mathrm{~h}$ and at $168 \mathrm{~h}$, respectively. These facts suggest that the difference in respiratory bursts of shrimp administered different levels of Lac. plantarum-contained diets was a consequence of increases in the activity of SOD, which catalyses the superoxide 
anion to hydrogen peroxide inducing an increase in PE gene transcription. Therefore, Lac. plantarum administration can enhance the situation with shrimp antioxidation.

The recognition protein, lipopolysaccharide and $\beta$-1, 3-glucan binding (LGBP) protein [8,53], a serine protease (SP) [4], and the cell adhesive protein, peroxinectin (PE) [13,15,54], are immune molecules relative to the proPO system. In this study, only PE of shrimp fed the Lac. plantarum-containing diet significantly increased after $168 \mathrm{~h}$, suggesting that an increase in PE can increase the biological activities of cell adhesion [9], opsonin [11], degranulation [12], peroxidase [13], and encapsulation [14] of shrimp.

Phagocytosis is an important cellular defence mechanism, whereas clearance efficiency is an important humoral defence mechanism in crustaceans [55]. There was significantly higher serum lysozyme activity in rainbow trout fed Lac. rhamnosus [41], and fed C. divergens B33 [25]. In the present study, the clearance efficiency significantly increased in L. vannamei following feeding of the $10^{7}$ and $10^{10} \mathrm{cfu}(\mathrm{kg} \mathrm{diet})^{-1}$ Lac. plantarum-containing diets from 48 to $168 \mathrm{~h}$, suggesting that Lac. plantarum was beneficial to shrimp in terms of enhancing the humoral immune response which may compensate for the decrease in PO activity after $48 \mathrm{~h}$ of feeding. Further research is necessary to determine the humoral immune parameters such as antimicrobial peptides of shrimp receiving Lac. plantarum.

In order to get information about the mechanism on the immune system of shrimp by probiotic stimulation, more experiments are needed to confirm the immune response of shrimp fed with dead or lysed La. Plantarum contained diets. Additional information about molecular characteristics of the lysed La. Plantarum surface, and compared with those from other probiotics, could also be useful to understand the chemical nature of the stimulus.

In conclusion, the Lactobacillus plantarum culture was beneficial for white shrimp in terms of resisting challenge by Vibrio alginolyticus and enhancing cellular and humoral immune responses, such as PO activity, SOD activity, and clearance efficiency against $V$. alginolyticus, and proPO and PE mRNA transcription levels.

\section{References}

[1] Tsing A, Arcier JM, Brehèlin M. Haemocytes of penaeids and palaemonid shrimps: morphology, cytochemistry and hemograms. J Invertebr Pathol 1989;53:64-77.

[2] Johansson MW, Söderhäll K. Cellular immunity in crustaceans and the proPO system. Parasitol Today 1989;5:171-6.

[3] Söderhäll K, Cerenius L, Johansson MW. The prophenoloxidase activating system in invertebrates. In: Söderhäll KS, Iwanaga GR, Vasta Gr, editors. New directions in invertebrate immunology. Fair Haven, NJ, USA: SOS Publications; 1996. p. $229-53$.

[4] Perazzolo LM, Barracco MA. The prophenoloxidase activating system of the shrimp Penaeus paulensis and associated factors. Dev Comp Immunol 1997;21:385-95.

[5] Smith VJ, Söderhäll K, Hamilton M. $\beta$-1.3-glucan induced cellular defense reaction in the shore crab, Carcinus maenas. Comp Biochem Physiol 1984;77A:636-9.

[6] Vargas-Albores F, Yepiz-Plascencia G. Beta glucan binding protein and its role in shrimp immune response. Aquaculture 2000;191:13-21.

[7] Sritunyalucksana K, Wongsuebsantati K, Johansson MW, Söderhäll K. Peroxinectin, a cell adhesive protein associated with the proPO system from the black tiger shrimp, Penaeus monodon. Dev Comp Immunol 2001;25:353-63.

[8] Cheng W, Liu CH, Tsai CH, Chen JC. Molecular cloning and characterisation of a pattern recognition molecule, lipopolysaccharide- and $\beta$ 1,3-glucan binding protein (LGBP) from the white shrimp Litopenaeus vannamei. Fish Shellfish Immunol 2005;18:297-310.

[9] Johansson MW, Söderhäll K. Isolation and purification of a cell adhesion factor from crayfish blood cells. J Cell Biol 1988;106: $1795-803$.

[10] Liang Z, Lindblad P, Beauvais A, Johansson MW, Latgé JP, Hall M, et al. Crayfish $\alpha$-macroglobulin and 76 kD protein; their biosynthesis and subcellular localization of the $76 \mathrm{kD}$ protein. J Insect Physiol 1992;38:987-95.

[11] Thörnqvist PO, Johansson MW, Söderhäll K. Opsonic activity of cell adhesion proteins and $\beta$-1,3-glucan-binding proteins from two crustaceans. Dev Comp Immunol 1994;18:3-12.

[12] Johansson MW, Söderhäll K. A cell adhesion factor from crayfish haemocytes has degranulating activity towards crayfish granular cells. Insect Biochem 1989;19:183-90.

[13] Johansson MW, Lind MI, Holmblad T, Thörnqvist PO, Söderhäll K. Peroxinectin, a novel cell adhesion protein from crayfish, blood. Biochem Biophys Res Commun 1995;216:1079-87.

[14] Kobayashi M, Johansson MW, Söderhäll K. The $76 \mathrm{kDa}$ cell-adhesion factor from crayfish haemocytes promotes encapsulation in vitro. Cell Tissue Res 1990;260:113-8.

[15] Liu CH, Cheng W, Kuo CM, Chen JC. Molecular cloning and characterisation of a cell adhesion molecule, peroxinectin from the white shrimp Litopenaeus vannamei. Fish Shellfish Immunol 2004;17:13-26.

[16] Muñoz M, Cedeño R, Rodriguez J, Van der Knaap WPW, Mialhe E, Bachère E. Measurement of reactive oxygen intermediate production in haemocyte of the penaeid shrimp, Penaeus vannamei. Aquaculture 2000;191:89-107.

[17] Bell KL, Smith VJ. In vitro superoxide production by hyaline cells of the shore crab Carcinus maenas (L.). Dev Comp Immunol $1993 ; 17: 211-9$. 
[18] Fuller R. A review: probiotics in man and animals. J Appl Bacteriol 1989;66:365-78.

[19] McCracken VJ, Gaskins HR. Probiotics and the immune systems. In: Tannock GW, editor. Probiotics: a critical review. Wymondham, England: Horizon Scientific Press; 1999. p. 85-112.

[20] Verschuere L, Rombaut G, Sorgeloos P, Verstraete W. Probiotic bacteria as biological control agents in aquaculture. Microbiol Mol Biol Rev 2000;64:655-71.

[21] Gatesoupe FJ. The use of probiotics in aquaculture. Aquaculture 1999;180:147-65.

[22] Irianto A, Austin B. Probiotics in aquaculture. J Fish Dis 2002;25:633-42.

[23] Maeda M, Liao IC. Effect of bacterial population on the growth of a prawn larva, Penaeus monodon. Bull Natl Res Inst Aquacult 1992;21:25-9.

[24] Rengpipat S, Phianphak W, Piyatiratitivorakul S, Menasveta P. Effects of a probiotic bacterium on black tiger shrimp Penaeus monodon survival and growth. Aquaculture 1998;167:301-13.

[25] Kim DH, Austin B. Innate immune responses in rainbow trout (Oncorhynchus mykiss, Walbaum) induced by probiotics. Fish Shellfish Immunol 2006;21:513-24.

[26] Ashenafi M, Busse M. Growth potential of Salmonella infantis and Escherichia coli in fermenting tempeh made from horsebean, pea and chickpea and their inhibition by Lactobacillus plantarum. J Sci Food Agric 1991;55:607-15.

[27] Cebeci A, Gürakan C. Properties of potential probiotic Lactobacillus plantarum strains. Food Microbiol 2003;20:511-8.

[28] Cheng W, Liu CH, Kuo CM, Chen JC. Dietary administration of sodium alginate enhances the immune ability of white shrimp Litopenaeus vannamei and its resistance against Vibrio alginolyticus. Fish Shellfish Immunol 2005;18:1-12.

[29] Robertson L, Bray W, Leung-Truillo J, Lawrence A. Practical molt staging of Penaeus setiferus and Penaeus stylirostris. J World Aquacult Soc 1987;18:180-5.

[30] Hernández-López J, Gollas-Galván T, Vargas-Albores F. Activation of the prophenoloxidase system of the brown shrimp (Penaeus californiensis Holmes). Comp Biochem Physiol 1996;113C:61-6.

[31] Liu CH, Chen JC. Effect of ammonia on the immune response of white shrimp Litopenaeus vannamei and its susceptibility to Vibrio alginolyticus. Fish Shellfish Immunol 2004;16:321-34.

[32] Bradford MM. A rapid and sensitive method for the quantitation of microgram quantities of protein using the principle of protein-dye binding. Anal Biochem 1976;72:248-54.

[33] Chomczynski P, Sacchi N. Single-step method of RNA isolation by acid guanidinium thiocyanate-phenol-chloroform extraction. Anal Biochem 1987;162:156-9.

[34] Lai CY, Cheng W, Kuo CM. Molecular cloning and characterisation of prophenoloxidase from haemocytes of the white shrimp, Litopenaeus vannamei. Fish Shellfish Immunol 2005;18:417-30.

[35] Jiménez-Vega F, Vargas-Albores F, Söderhäll K. Characterisation of a serine proteinase from Penaeus vannamei haemocytes. Fish Shellfish Immunol 2005;18:101-8.

[36] Schiffrin EJ, Rohat F, Link-Amster H, Aeschlimann JM, Donnet-Hughes A. Immunomodulation of human blood cells following the ingestion of lactic acid bacteria. J Dairy Sci 1995;78:491-7.

[37] Herías MV, Hessle C, Telemo E, Midtvedt T, Hanson LÅ, Wold AE. Immunomodulatory effects of Lactobacillus plantarum colonizing the intestine of gnotobiotic rats. Clin Exp Immunol 1999;116:283-90.

[38] Irianto A, Austin B. Use of probiotics to control furunculosis in rainbow trout, Oncorhynchus mykiss (Walbaum). J Fish Dis 2002;25: $333-42$.

[39] Villamil L, Tafalla C, Figueras A, Novoa B. Evaluation of immunomodulatory effects of lactic acid bacteria in turbot (Scophthalmus maximus). Clin Diagn Lab Immunol 2002;9:1318-23.

[40] Nikoskelainen S, Ouwehand AC, Bylund G, Salminen S, Lilius EM. Immune enhancement in rainbow trout (Oncorhynchus mykiss) by potential probiotic bacteria (Lactobacillus rhamnosus). Fish Shellfish Immunol 2003;15:443-52.

[41] Panigrahi A, Kiron V, Kobayashi T, Puangkaew J, Satoh S, Sugita H. Immune responses in rainbow trout Oncorhynchus mykiss induced by a potential probiotics bacteria Lactobacillus rhamnosus JCM 1136. Vet Immunol Immunopathol 2004;102:379-88.

[42] Salinas I, Cuesta A, Esteban MA, Meseguer J. Dietary administration of Lactobacillus delbrueckii and Bacillus subtilis, single or combined, on gilthead seabream cellular innate immune responses. Fish Shellfish Immunol 2005;19:67-77.

[43] Chang CI, Liu WY. An evaluation of two probiotic bacterial strains, Enterococcus faecium SF68 and Bacillus toyoi, for reducing edwardsiellosis in cultured European eel, Anguilla anguilla L. J Fish Dis 2002;25:311-5.

[44] Nikoskelainen S, Ouwehand AC, Salminen S, Bylund G. Protection of rainbow trout (Oncorhynchus mykiss) from furunculosis by Lactobacillus rhamnosus. Aquaculture 2001;198:229-36.

[45] Maeda M. Biocontrol of the larvae rearing biotope in aquaculture. Bull Natl Res Inst Aquacult 1994;1:71-4.

[46] Persson M, Cerenius L, Söderhäll K. The influence of haemocyte number on the resistance of the freshwater crayfish Pacifastacus leniusculus Dana, to the parasitic fungus, Aphanomyces astaci. J Fish Dis 1987;10:471-7.

[47] Smith VJ, Johnston PA. Differential haemotoxic effect of PCB congeners in the common shrimp, Crangon crangon. Comp Biochem Physiol 1992;101C:641-9.

[48] Cheng W, Chen JC. Effects of intrinsic and extrinsic factors on the haemocyte profile of the prawn, Macrobrachium rosenbergii. Fish Shellfish Immunol 2001;11:53-63.

[49] Truscott R, White KN. The influence of metal and temperature stress on the immune system of crabs. Funct Ecol 1990;4:455-61.

[50] Le Moullac G, Soyez C, Saulnier D, Ansquer D, Avarre JC, Levy P. Effect of hypoxia stress on the immune response and the resistance to vibriosis of the shrimp Penaeus stylirostris. Fish Shellfish Immunol 1998;8:621-9.

[51] Brady YJ, Lasso de la Vega E. Recovery of Serratia marcescens in haemolymph of Macrobrachium rosenbergii from experimentally seeded water. J World Aquacult Soc 1992;23:228-31. 
[52] Campa-Córdora AI, Hernández-Saaveda NY, De Philippis R, Ascencio F. Generation of superoxide-anion and SOD activity in haemocytes and muscle of American white shrimp (Litopenaeus vannamei) as a response to $\beta$-glucan and sulphated polysaccharide. Fish Shellfish Immunol 2002;12:353-66.

[53] Lee SY, Wang R, Söderhäll K. A lipopolysaccharide- and $\beta$-1,3-glucan-binding protein from hemocytes of the freshwater crayfish Pacifastacus leninusculus. Purification, characterization, and cDNA cloning. J Biol Chem 2000;275:1337-43.

[54] Liu CH, Cheng W, Chen JC. The peroxinectin of white shrimp Litopenaeus vannamei is synthesised in the semi-granular and granular cells, and its transcription is up-regulated with Vibrio alginolyticus infection. Fish Shellfish Immunol 2005;18:431-44.

[55] Ratcliffe NA, Rowley AF, Fitzgerald SW, Rhodes CP. Invertebrate immunity: basic concepts and recent advances. Int Rev Cytol 1985;97:183-350. 